\title{
Language Impoliteness Strategies Used by Headmaster with Reference to the Level of Education in School Area
}

\author{
Khairunnisa $^{1, *}$ Amrin Saragih ${ }^{2}$ Sri Minda Murni ${ }^{3}$ \\ ${ }^{1}$ Universitas Negeri Medan, Medan, Indonesia \\ ${ }^{2}$ Universitas Negeri Medan, Medan, Indonesia \\ ${ }^{3}$ Universitas Negeri Medan, Medan, Indonesia \\ *Corresponding author. Email: khairunnisapiliang06@gmail.com, amrin_saragih@yahoo.com, \\ srimindamurni25@gmail.com
}

\begin{abstract}
This study deals with the language impoliteness used by headmaster with reference to the level of education in school area. The objective of this study was to categorize the types of language impoliteness which are uttered by headmaster in school area. This research was conducted by using the study that deploying Culpeper's Impoliteness as an analytical approach. The data were utterances from headmaster and the source of data taken from school area. The result of the data showed that there were five types of language impoliteness used by headmaster with reference to the level of education in school area as bald on record impoliteness $(6.3 \%)$, positive impoliteness $(2.1 \%)$, negative impoliteness $(46.8 \%)$, sarcasm or mock impoliteness $(36.2 \%)$ and withhold politeness $(8.6 \%)$. The most dominant type of language impoliteness was negative impoliteness, the lowest type of language impoliteness was positive impoliteness.
\end{abstract}

Keywords: impoliteness strategies, negative impoliteness, positive impoliteness.

\section{INTRODUCTION}

Interaction has an important role in communicating in human life. The interaction in society determines the harmonious relationship among people. Interaction is the heart of communication. It is expected by having a good interaction; every individual in the community can avoid the conflict and give a peace among them [1].

As social creatures, people have an essential need which is to communicate with others to exchange messages, answer questions, and express some ideas. Conversation is the most common process of communication which involves two people or more. In conversations, people use language to send their thoughts and opinions. In sending their messages, people often use different styles and ways. Some of them choose their words wisely and tend to apply polite language because they expect to have smooth conversation. Nevertheless, smooth conversation sometimes cannot be achieved because there are some people who do not care about words choice
One way to optimize the interaction among societies is by using polite language. It is needed so that be harmonious relationship could be achieved. Since a school is a place where normally found that people who are stakeholders in a school, including students, teachers, headmaster, vice headmaster and all staffs must utter language politely.

Moreover, a place where polite language is really needed is in the interaction of a school. Between headmaster, teachers, and students are expected to utter polite language in order to maintain the harmonious relationship among the moreover to avoid conflict. The good interaction among them will create an enjoyable atmosphere. Headmaster as a model, a motivator, an educator and a facilitator have important roles in a school. In communication process, the interaction as being built up of different expressions which may be used to attempt, establish and maintain social and professional relationship.

Nowadays, it seems to be disruption in communicate where politeness is ignored and impoliteness is more likely to be used by people. Impoliteness is a field of 
pragmatics that has become relatively popular in recent years but has not gained nearly as much attention as linguistic politeness [2]. In line with this, Impoliteness as a communicative strategy designed to attack face and hereby cause social conflict and disharmony [3]. The phenomenon of impoliteness is to do how often is conducted upon the language. The language impoliteness will cause the social conflict and disharmony between headmaster, teachers and students.

The different expressions do not include linguistic features such as words but also gestures, pauses and tone. In using these expressions, it is a good way choosing strategically relevant language to initiate and maintain interaction. It depends on the reason to communicate or interact that the headmaster, teachers and students may fulfill socially recognized and accepted ways of requesting, offering, suggesting, complaining for example. The language chosen in these instances would then include indirect expressions and implication.

Politeness focuses on how communicative strategies are employed to maintain social harmony. In contrast, disharmony also can happen when the speaker is attacking the interlocutor's public self-image. Some people prefer to use impolite language than the polite one because of several factors.

The previous study impoliteness researches mostly deal with the occurrence of Students' Perceptions towards Teachers' and Students' Academic Impoliteness. The aim of this study was to examine Iranian university students' perception towards university students' and instructors' academic impoliteness. They found that both students' and instructors' impolite behavior have been as a serious problem that highly interferes with the goals of education. The result indicated that academic incivility can be recognized a verbal, non-verbal, and/or as a combination of both. This study creates awareness about academic impoliteness especially in Iranian context and it might be a step towards tackling it. This phenomenon can also happen in Indonesia schools

Based on the phenomena and relevant studies above, the researcher is interested in analyzing the headmaster utterances in school area. The problem of the study is to found out the type of language impoliteness strategy that used by headmasters with reference to the level of education in school area.

\subsection{Impoliteness}

Language impoliteness is the opposite of language politeness. Politeness has been studied a lot more thank impoliteness. However, it is more usual that people comment on impolite feature of the discourse. The behavior that is impolite, rude, discourteous, obstreperous or bloody-minded is noticed more easily than polite behavior. When someone acts impolitely, he/she is breaking the rules of politeness by deliberately attacking others with his/her speech.
The notion of impoliteness is the communicative strategies designed to attack face, and thereby cause social conflict and disharmony. The concept of impoliteness in Pragmatic and Sociolinguistics has always been as depend on the context [4]. The context which is seen from the utterances which is supported by applying attitude and management of face can be determined as polite or impolite one. In other words, ac action may be said as impolite act if the hearer considered that the speaker damages the hearer's face and appeared to threaten action.

\subsection{Type of Impoliteness}

Based on those of impoliteness strategies, the five impoliteness strategies will use in answering the research problem, namely bald on record impoliteness, positive impoliteness, negative impoliteness, sarcasm or mock politeness and withhold politeness.

Bald on record impoliteness is a strategy which used by the people with say impolite utterance to someone using face attacks before or when someone is saying impolite utterances. It means this strategy is a first thing when people hear impolite utterances. With use the face attack, the people will know if other people do not like with the people. Positive impoliteness is a strategy that is use to ignore or show a disrespectfully to someone but with a positive face or answer. It means that this strategy is a way to show a dislike thing to someone. The people just show the face like fake smile, fake word, and others but the aim is to show disrespectfully. This strategy also is a good way to show how people do not like someone without make their heart sick. With this strategy, a violence thing will be reduced because other people will not get offend to someone. Negative impoliteness is the opposite of positive impoliteness. This strategy shows how people dislike to someone clearly. It means these strategies one of the things that can make the violence will be happen. Negative impoliteness is the use of strategy designed to damage the addressee's negative face. Negative face is the desire for "freedom of action". Sarcasm is a politeness strategy that is done insincerely or can be attributed to actual intentions. The purpose of sarcasm is a satirize or offend someone. The person using this strategy with some words is to offend other people some words is to offend other people will get angry to the speaker. This strategy shows a dislike to someone with say a joke to someone. Every people usually see this strategy in social interaction. Withhold politeness is used by people to expect the politeness because politeness is not used. The example is when people silent when other people say thanks to the people. It is because when people not respond when other people say; the people will argue if people do not have a polite manner. The people cannot silent when other people say thanks or say anything to other people. It is supported by gives the example that "failing to thanks someone for a present may be taken as deliberate impoliteness. 


\section{METHOD}

This study conducted by using descriptive qualitative design which case study in order the language impoliteness used by headmaster. The design used in this research refers to the researcher's plan of how to proceed [6]. Data was the rough materials researchers collect form the world they are studying: data were the particular that form the basis of analysis.

The data of this study was headmasters' impolite utterances in the school area. The source of data was from three headmasters with different level of education. There are Primary School Headmaster, Junior High School Headmaster and Senior High School Headmaster. The headmasters used language impoliteness toward to teachers and students in the school.

The place for the research took the data was at Perguruan Aisyiyah Pargodungan, Tapanuli Tengah. The researcher gather the data by doing observation and take notes of it.

\section{RESULT AND DISCUSSION}

There are five types of impoliteness strategies proposed by Culpeper. They are 1) Bald on Record Impoliteness, 2) Positive Impoliteness, 3) Negative Impoliteness, 4) Sarcasm/ mock Politeness and 5) Withhold Politeness.

Moreover, after analyzing the data it found all types in impoliteness strategies in this research. They are 1) Bald on Record Impoliteness, 2) Positive Impoliteness, 3) Negative Impoliteness, 4) Sarcasm/ mock Politeness and 5) Withhold Politeness. The summarized of the types and percentages are listed in the following Table 1 . The proportion of each is also displayed in the table. First it will be shown in the table then it will be described narratively.

Table 1. Proportion of Impoliteness Strategies used by Head Master

\begin{tabular}{|l|l|l|l|}
\hline No & Types & Frequency & $\begin{array}{l}\text { Percentages } \\
(\mathbf{\%})\end{array}$ \\
\hline 1. & $\begin{array}{l}\text { Negative } \\
\text { Impoliteness }\end{array}$ & 22 & 46.8 \\
\hline 2. & $\begin{array}{l}\text { Sarcasm/ Mock } \\
\text { Impoliteness }\end{array}$ & 17 & 36.2 \\
\hline 3. & $\begin{array}{l}\text { Withhold } \\
\text { Politeness }\end{array}$ & 4 & 8.6 \\
\hline 4. & $\begin{array}{l}\text { Bald on Record } \\
\text { Impoliteness }\end{array}$ & 3 & 6.3 \\
\hline 5. & $\begin{array}{l}\text { Positive } \\
\text { Impoliteness }\end{array}$ & 1 & 2.1 \\
\hline Total & 47 & $100 \%$ \\
\hline
\end{tabular}

The table above shown the types of impoliteness strategies in head master. The most dominant type used is negative impoliteness which is $46.8 \%$, followed by sarcasm / mock politeness with $36.2 \%$ each, Withhold Politeness with $8.6 \%$, Bald on record with $6.3 \%$ and last positive impoliteness which is $2.1 \%$. So, in this research, the researcher fined that positive impoliteness is the least used by the head master. The reason why negative impoliteness got the highest because the head master shows how she dislike to someone clearly. It means these actions was a thing that can make the violence will be happen, also the head master mostly utter to damage the addressee's negative face. Moreover, why positive impoliteness got the lowest number because the head master rarely show a dislike thing to someone by showing like fake smile, fake word, or others but the aim is to show disrespectfully.

The analysed can be seen below. The following data showed that the head master expressed Negative Impoliteness

Context: Kepala sekolah marah kepada guru karena dia menemukan ada guru yang berkumpul dan ngobrol di meja piket.

'Headmaster was angry at teachers because he / she finds teacher was gathering and having chit - chat in meja piket'.

MR: $\quad$ Ibu - ibu guru di sini ngapain? (menyernyitkan dahi, tanda tidak suka)

'All teacahers, what are you doing here? (frowned and show a hate face)'.

Guru-guru: Ngobrol

(Teachers): 'Having conversation'

MR: $\quad$ Guru di sini dibayar untuk mengajar bukan untuk menggossip.

'Teacher here was paid for teaching not gossiping.'

Guru-guru: Iya, bu.

(Teachers): 'Yes, Mam'

In this case MR was angry because he saw that the teachers gather around and gossiping in the table. In his mind teachers should be teaching not gossiping that's why he uttered that teacher got paid for teaching not gossiping. The headmaster venting the negative feeling by insulting the theacher with 'here you paid for teaching not gossiping'.

The following data showed that the head master expressed sarcasm.

Context: Kepala sekolah marah dan menghukum murid di kantor

'Headmaster was angry at students who got punished in the office.

LW: $\quad$ Kau - kau aja ku tengok yang bermasalah. Capek aku menghadapinya. 
'Its always you that I saw. So tired to face you.'

Student: (menunduk)

(head down)

LW: Jadi beban negara aja kau. Gak ada gunamu.

'Become a state burden. No benefit.'

Murid: (diam)

(Silent)

From the data above we can see that LW's utterance condescend the student, due to the student bad behaviour LW stated that the student was become a burden fs the government. It was an abbreviation in Bahasa to state if someone was useless.

The following data showed that the head master expressed withhold impoliteness.

Context: $\quad$ Seorang guru memberi laporan mengenai kegiatan luar sekolah kepada kepala sekolah di kantor tetapi kepala sekolah tidak memberikan balasan.

'A teacher giving a report about students' extra cullicular activity to headmaster's office but headmaster didn't give nice respond.'

DW: $\quad$ Assalamualaikum, Bu.

'Assalamualaikum, Mam.'

MR: $\quad$ Waalaikumsalaam. (menulis di buku)

'Waalaikumsalaam. (writing on a book)'

DW: $\quad$ Ini saya mau kasih laporan kegiatan murid bidang klub Bahasa Inggris.

'I want to give you a report on the activities of students in the English club.'

MR: $\quad H m m$ (menggumam dan masih menulisi di buku)

'Hm. (just mumbling and keep on writing on the book)'

DW: $\quad$ Sudah ini saja, Bu? Saya izin keluar ya, bu.

MR: $\quad H m$. (mengibaskan tangan)

'Hm. (flapping hands)'

From the data above we know that MR was doing something with his paper, doing several works. But in this case a teacher came and wanting to give report. We saw above MR failed to show her gratitude towards DW, when MR supposed to say thank you instead of saying hmmmm.
The following data showed that the head master expressed bald on record.

Context: Kepala sekolah mengevaluasi RPS guru

'Headmaster evaluate teachers' lesson plan'.

$\mathrm{KN}$ : (menunjukan wajah tidak suka) Pak (nama), kemarin kan saya minta bapak untuk perbaiki prota sama prosem bapak. Amburadul, gakngerti saya itu gimana. Tapi ini saya lihat gak ada perubahan.

'(showing a hate face), Sir (name), yesterday I ask you to revise this prota and prosem. It's all a mess. I don't understand, I didn't saw any changes'.

PM: $\quad$ Itu sudah saya perbaiki, Pak.

"I have revised it'.

KN: $\quad$ Tidak seperti ini yang saya minta. Ngerti gak sih, Pak? Masa perlu diajarin satu satu lagi macam murid SD yang goblok itu? 'not like this that I want, don't you understand, sir? Should I teach you one by one, like a stupid kid?'.

PM: $\quad$ (diam)

(silent)

In the data above we can see that $\mathrm{KN}$ used so much face attack 'showing a hate face while calling the teacher name', and also performed the clear face threatening 'it's all a mess' and $\mathrm{KN}$ also showed her power by saying that the result of the prota and prosem was a messed. KN got angry because PM accused by saying that he has revised the paper but in fact KN was not satisfy.

The following data showed that the head master expressed Positive Impoliteness.

Context: Kepala sekolah dan guru-guru sedang berkumpul di ruang kantor pada jam istrahat. Tiba-tiba ada seorang guru wanita yang bertanya kepada kepala sekolah mengenai dirinya.

'The principal and teachers are gathered in the office at break time. Suddenly a female teacher asked the principal about her'.

Teacher: Bu, cantik aku kan?

'Mam, I am pretty right'?

MR: $\quad$ Iya cantik, tapi sayang, jomblo (tidak punya pasangan).

'Yes, beautiful but single'.

Teacher: Hmm ya ibu (sambil menundukkan pandangan)

'Hmmm yes Mam (look at the floor)' 
From the data above it can be seen clearly that MR is giving a positive reply when one of the teachers asking but, in the end, MR say pretty with addition 'no boyfriend'. In this case MR is praise the teacher but also unconsciously destroy teacher positive face.

For the discussion, this result is contradictory from the previous study, which withhold politeness wasn't found. Previous study discuss the impoliteness strategies that occur in Mail Online's entertainment news comment section by using the theory of impoliteness by Jonathan Culpeper.

This research uses a qualitative method with a pragmatic approach. It aims to describe the types and functions of impoliteness strategies that occur in 10 Mail Online's entertainment news comment section. It uses 50 utterances to analyses that taken from 10 articles in Mail Online's entertainment news comment section which published from March 2019 until April 2019

\section{CONCLUSION}

This study cantered on the language discourtesy employed by head master. It had been aimed to seek out the of discourtesy ways and to elucidate the rationale why language discourtesy employed by the headmaster.

The conclusion of the research is there were five types of language discourtesy used the scholars in school interaction, particularly 1) bald on record discourtesy, 2) positive discourtesy, 3) negative discourtesy, 4) sarcasm / mock, and 5) withhold politeness. Negative Impoliteness discourtesy was the foremost dominant ways employed by the head master and also the least strategy was Positive Impoliteness.

In this section, there were some points which were considered the important things to be discussed based on Culpeper (2005) there were 5 Impoliteness Strategies and all of them were found in this research. The most dominant type used is Negative Impoliteness which is $46.8 \%$, followed by Sarcasm / Mock Politeness with $36.2 \%$ each, Withhold Politeness with $8.6 \%$, Bald on Record Impoliteness with $6.3 \%$, and last Positive Impoliteness which is $2.1 \%$.

\section{REFERENCES}

[1] Brown, D.H., "Teaching by Principles: An Interactive Approach to Language Pedagogy. White Plains", NY: Pearson Education. Longman, 2011.

[2] Pennanen, S.P., "The Structure of Impolite Events in Computer-Mediated Conversation (Pro-Gradu Thesis," University of Helsinki), 2013.

[3] Culpeper, J., Conventionalized impoliteness formulae, Journal of Pragmatics, vol.42,pp. 32323245,2010 .
[4] Culpeper, J., D Bousfield . and Whichmann. (2003) Impoliteness Revisited: With Special Reference to Dynamic and Prosodic Aspects. Journal of Pragmatics 35, 1546-1579.

[5] Culpeper, J., "Impoliteness and entertainment in the television quiz show: The Weakest Links.Journal of Politeness Research. Language, Behaviour, Culture", 35-72., 2005.

[6] Bogdan, R and Biklen., "Qualitative Research for Education (2ndEd)", Bosto: Allan and Bacon, 1982.M. Young, The Technical Writer's Handbook. Mill Valley, CA: University Science, 1989. 